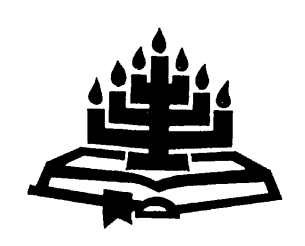

\title{
Die teologies-polemiese gerigtheid van Genesis 1-3: implikasies vir die gereformeerde leer oor die erfsonde
}

\author{
N. Vorster \\ Skool vir Kerkwetenskappe \\ Potchefstroomkampus \\ Noordwes-Universiteit \\ POTCHEFSTROOM \\ E-pos: nvorster@telkomsa.net
}

\begin{abstract}
The theological polemic purpose of Genesis 1-3: implications for the reformed doctrine on original sin

This article focuses on the polemic nature of Genesis 1-3 and the implications thereof on the reformed doctrine regarding original sin. In the first place the views of the creation narratives as historical-literal and mythological material are discussed. Thereafter the article proposes that the creation narratives must be treated as theological material with a polemic and prophetic purpose. The implications of this for the reformed doctrine on original sin are subsequently discussed.
\end{abstract}

\section{Opsomming}

Die teologies-polemiese gerigtheid van Genesis 1-3: implikasies vir die gereformeerde leer oor die erfsonde

Hierdie artikel probeer 'n bydrae maak tot hernude besinning oor die Christelike skeppingsleer deur te fokus op die polemiese gerigtheid van Genesis 1-3 en die implikasies wat dit vir die gereformeerde leer oor die erfsonde het. Dit bespreek in die eerste plek die siening van Genesis 1-3 as histories-letterlike en mitologiese stof. Daarna stel dit voor dat Genesis 1-3 as teologiese stof met 'n polemiese en profetiese gerigtheid hanteer word. Vervolgens word die implikasies hiervan vir die gereformeerde leer oor die erfsonde bespreek. 


\section{Inleidend}

Die skeppingsleer geniet nuwe prominensie in die dogmatiek weens verskeie redes. In die eerste plek is Genesis 1-3 van besondere belang vir 'n Christelike antropologie. Die moderne Christelike tradisie gebruik hoofsaaklik die mens se beeldskap van God as begronding vir 'n Christelike konsep van menswaardigheid en menseregte. Tweedens lei die ekologiese krisis tot hernude besinning oor die Christelike skeppingsleer (vgl. Rogerson, 2001:38). Tot watter mate het 'n onverantwoordelike eksegese van Genesis 1:26-28 bygedra tot die ekologiese krisis? Die historikus Lynn White (1967: 1203-1207) het byvoorbeeld groot opslae gemaak toe hy die Christendom beskuldig het van 'n aandadigheid aan die ekologiese krisis wat volgens hom voortvloei uit die Christendom se verstaan van die kultuuropdrag in Genesis 1:26-28. Die vraag is: Hoe kan die Christelike skeppingsleer bydra tot 'n verantwoordelike Christelike omgewingsetiek? Derdens het natuurwetenskaplike uitvindings klassieke histories-letterlike verklarings van Genesis 1-3 as agtergehaal bewys. Hernude besinning oor die boodskap van Genesis 1-3 is daarom nodig.

Hierdie artikel fokus op die polemiese gerigtheid van Genesis 1-3 en die implikasies daarvan vir die gereformeerde leer oor die erfsonde. Dit bespreek allereers die siening van Genesis 1-3 as historiesletterlike en mitologiese stof. Daarna stel dit voor dat Genesis 1-3 as teologiese stof met 'n polemiese en profetiese gerigtheid hanteer word. Ten slotte word die implikasies hiervan vir die gereformeerde leer oor die erfsonde bespreek.

\section{Histories-letterlike benadering}

Die histories-letterlike benadering is in die Middeleeue deur die Rooms Katolisisme gevolg en in die moderne tyd deur die fundamentalistiese beweging wat in die vroeg twintigste eeu in NoordAmerika ontstaan het. Sommige konserwatiewe teoloë soos Louis Berkhof (1958:141) handhaaf ook die siening dat die skeppingsverhale histories-letterlike stof is. Volgens die histories-letterlike siening moet die skeppingsverhale streng letterlik verklaar word. Die Bybel word gesien as 'n boek wat benewens sy teologiese boodskap ook natuurwetenskaplike inligting gee. Die aarde is ongeveer 6000 jaar oud en is in ses dae van 24 uur geskape. Fundamentalistiese bewegings poog dikwels om pseudowetenskaplike gegewens te verskaf wat die Bybelse skeppingsverhale reg bewys. Die histories-letterlike benadering skep egter onhoudbare probleme. 


\subsection{Spanning met moderne wetenskap}

In die eerste plek maak ' $n$ histories-letterlike benadering van Genesis 1-3 die Bybel ongeloofbaar, omdat dit die Bybel in konflik met bewese wetenskaplike feite bring. Die wetenskap het byvoorbeeld reeds bewys dat die aarde biljoene jare oud is, terwyl fossiele van diere gevind is wat ook miljoene jare oud is. Die wetenskaplike metodes wat gebruik word om ouderdomme te bepaal soos die koolstofdioksiedtoets, die voorkoms van ringe in fossiele en toetse op yslae is redelik eenvoudig en die resultate kan op verskeie maniere gekontroleer word. Wetenskaplikes het verder reeds aangetoon dat die sterrestelsel miljarde jare oud is wanneer die aantal ligjare bereken word wat dit hulle lig neem om die aarde te bereik.

Binne kreasionistiese kringe ${ }^{1}$ word hierdie wetenskaplike bevindings soms op epistemologiese gronde bevraagteken. Die argument is dat alle wetenskaplike kennis deur vooronderstellings beïnvloed word en daarom voorlopig van aard is (vgl. Velema \& Van Genderen, 1992:260). Wetenskap word beskryf as "louter teorie". Natuurlik word alle wetenskap deur vooronderstellings beïnvloed, maar dit is onjuis om te beweer dat die natuurwetenskappe net uit teorieë of modelle bestaan. Die geloofwaardigheid van natuurwetenskaplike teorieë kan getoets word aan empiries-verifieerbare resultate. Die wetenskap het byvoorbeeld duidelik en onweerlegbaar bewys dat die aarde rond is. Die stelling dat die aarde rond is kan nie afgemaak word as 'n "louter teorie" wat gegrond is op vooronderstellings nie. Die poging om natuurwetenskaplike bevindings oor die ouderdom van die aarde te bevraagteken op grond van epistemologiese argumente is ongeloofbaar en onoortuigend.

Du Toit (1964:40) het reeds in 1964 daarop gewys dat fundamentalistiese groeperings fouteer deur die Skrif en wetenskap op 'n onoortuigende en kunsmatige wyse te probeer versoen. Dit aanvaar dat die Bybel presiese wetenskaplike kennis weergee, en dat Genesis 'n moderne wetenskaplike wêreldbeeld bevat. Die waarheid van geloof word as wetenskaplik aanwysbaar beskou, met die gevolg dat openbaring en wetenskap op dieselfde vlak gestel word. Hierteenoor moet gestel word dat die eiesoortige aard van die Bybel gerespekteer moet word, en dat Skrif en wetenskap nie op 'n kunsmatige manier met mekaar versoen moet word nie. Die poëtiese taal in Genesis 1 wat na vore kom in simmetriese en her-

$1 \quad$ Kreasionisme is 'n denkrigting wat die skeppingsverhale letterlik interpreteer en as gesagvol op 'n nattuurwetenskaplike vlak beskou. 
halende patrone kan byvoorbeeld nie in wetenskaplike taal verander of vertaal word nie (vgl. Turner, 2000:19). Ons moet die Skrif en belydenis daarom in sy eie reg bestudeer. Natuurwetenskaplike gegewens mag nooit 'n bindende maatstaf vir Skrifverklaring wees nie. Andersyds kan natuurwetenskaplike ontdekkings egter help om te vra of die Bybel reg verstaan word. Indien wetenskaplike ontdekkings onteenseglik wys dat ons verklarings van die Skrif onhoudbaar is, moet teologiese dogmas herformuleer word ( $\mathrm{vgl}$. Du Toit, 1964:45, 46, 112; Bavinck, 1928b:458). Pogings om standpunte oor die skepping te verdedig wat duidelik nie waar is nie, bring die geloofwaardigheid van die Christendom in die gedrang.

\subsection{Die geosentriese wêreldbeeld in die Bybel}

Die implikasie van 'n histories-letterlike benadering is dat die geosentriese wêreldbeeld wat in Genesis 1:6-8 en die res van die Skrif voorkom noodwendig as 'n natuurwetenskaplike waarheid en as normatief bindend beskou moet word. Klassieke gereformeerde teoloë soos Kuyper, Bavinck en Vriezen gee toe dat die Bybel 'n geosentriese wêreldbeeld handhaaf (Bavinck, 1928b:446; Kuyper, s.a.:76, 78; Vriezen, 1977:361). Du Toit (1964:58-61) beskryf die geosentriese wêreldbeeld wat in die Bybel voorkom soos volg met verwysing na Skrifgedeeltes:

Volgens die geosentriese wêreldbeeld is die hemel 'n uitspansel of firmament wat die aarde omhul en die aardse en hemelse oseane uitmekaar hou (Gen. 1:6, 7; Job 26:11; Jes. 40:22). As die waters van die twee oseane saamvloei, kom die toestand van Gen. 1:2 weer tot stand. Dit is wat gebeur met die sondvloed (vgl. Gen. 7:11; Ps. 104:3; 148:4). Bokant die oseaan is die woning van God wat soos 'n hoë solder oor die oseaan rus (Ps. 29:10; 104:3). Daar word ook onderskei tussen verskeie hemele (1 Kon. 8:27; Deut. 10:14; Neh. 9:6; Ps. 148:4).

Die aarde word gesien as 'n goed-saamgevoegde gebou wat in die onderaardse waters ingesink is (1 Sam. 2:8; Spr. 8:25, 29; Job 9:6). Die aarde rus op die onderste oseaan of wêreldvloed (Gen. 1:2). Hierdie oseaan omgewe die aarde ook van alle kante (Ps. 104:6). Die aarde staan in 'n geheimnisvolle verbinding met die onderste waters deur bronne en strome. Hierdie verbinding kan noodlottig word wanneer die bronne van die 'groot dieptes' oopgaan (Gen. 7:11). Onder die aarde is die doderyk of Sjeool. Dit is die plek waarna goddelose mense gaan ná hulle dood. 
Teoloë wat die letterlike benadering volg, moet konsekwent wees in hulle benadering. Indien letterlike uitgangspunte aanvaar word soos dat die aarde 6000 jaar oud is en in ses dae van 24 uur geskape is, moet die geosentriese wêreldbeeld ook aanvaar word.

\subsection{Die ryke gevarieerdheid van materiaal oor die skepping in die Ou Testament}

In die Bybel word 'n ryke variasie van materiaal oor die skepping gevind. Hierdie materiaal is egter geensins sistematies van aard nie, en stem nie altyd feitelik ooreen nie. Dit bring egter nie die gesagvolheid en openbaringskarakter daarvan in die gedrang nie. Die Ou Testament bevat byvoorbeeld verskeie skeppingsweergawes en gee 'n perspektief met vele fasette op die verhouding tussen Skepper en skepping (Westermann, 1974:5). 'n Voorbeeld is die verskille tussen Genesis 1 en 2. Die orde waarin die skepsele geskape is verskil in die verhale. In hoofstuk 1: plante, diere, mense. In hoofstuk 2: die man, die tuin, die diere, die vrou. Die een verhaal speel af binne die konteks van 'n watermassa wat georden word, terwyl die ander binne die konteks van 'n woestyn afspeel. Genesis 1 praat van 'n skepping deur woorde, terwyl Genesis 2 dui op 'n skepping deur dade.

Die skeppingsweergawe wat in Genesis 2 gegee word, is onversoenbaar met Genesis 1 en gee beslis nie net 'n nadere verduideliking van natuurwetenskaplike feite in Genesis 1 soos historiesletterlike verklaarders beweer nie. Indien die histories-letterlike benadering gevolg word, sal noodwendig afgelei moet word dat hierdie verhale teenstrydig is (vgl. Barth, 1958:80). Inhoudelike teenstrydighede tussen die Genesisverhale en stof wat byvoorbeeld in profetiese literatuur voorkom, sou ook aangetoon kan word. Die vraag is egter: Waarom het die samestellers van Genesis twee skeppingsberigte wat ooglopende teenstrydige feite bevat langs mekaar geplaas? Waarom het hulle nie die twee weergawes probeer harmonieer nie? Die redigeerders het duidelik besef dat die twee verhale ditself nie as histories-letterlike stof voordoen nie, maar dat hulle eenheid op 'n teologiese vlak lê. König (1988:10) wys tereg daarop dat die ongeredigeerde verskille tussen Genesis 1 en 2 'n aanduiding is dat die redigeerders nie belanggestel het in die presiese wyse waarop alles ontstaan het nie, maar wel in die teologiese boodskap oor die verhouding tussen God en mens. Indien Genesis 1 en 2 histories-letterlik verklaar word, is hulle teenstrydig. Indien hulle egter teologies-profeties geïnterpreteer word, is hulle onlosmaaklik aan mekaar verbonde en vorm hulle 'n onlosmaaklike 
teologiese geheel. In Genesis 1 is dit die mens vir God en in Genesis 2 is dit God vir die mens. Die feit dat die twee skeppingsverhale uit verskillende bronne ontstaan het, beteken nie dat die twee skeppingsverhale nie as 'n teologiese eenheid gelees kan word nie. Dit is byvoorbeeld moontlik dat "P" Genesis 1-11 saamgestel het deur "J" in sy eie weergawe te inkorporeer (vgl. Rogerson, 2001:60).

\section{Die mitologiese verstaan van Genesis 1-3}

Die ontdekking van die Babiloniese skeppingsgeskrif, Enuma Elish, aan die einde van die negentiende eeu het vrae laat ontstaan oor die verband tussen die Bybelse skeppingsverhale en skeppingsmites wat in die Antieke Ooste voorgekom het. Genesis 1 toon byvoorbeeld sterk ooreenkomste met die Babiloniese skeppingsverhaal wat in die Enuma Elish-epos gevind word. Volgens Enuma Elish het alles aanvanklik uit chaos bestaan. ' $n$ Oorlog het ontstaan tussen Marduk, die god van orde, en Tiamat, die god van chaos. Marduk het die liggaam van Tiamat in twee geskeur en daaruit die waters bo die aarde en onder die aarde geskape, met die aarde in die middel. So het hy chaos in orde verander. Sedertdien is ontdek dat die weergawe in Enuma Elish op sy beurt sterk ooreenkomste toon met skeppingsmites wat in ander antieke kulture bestaan het. Die vraag is dus nie meer wat die verhouding tussen die Bybelse skeppingsverhale en Babiloniese skeppingsverhale is nie, maar wel oor hulle verhouding met ' $n$ hele tradisie van skeppingsmites wat oor duisende jare in die Antieke Ooste ontwikkel het. Die Jahwistiese skeppingsverhaal toon byvoorbeeld sterk ooreenkomste met 'n Mesopotamiese skeppingsmite wat oor die tuin Eden handel. In dié tuin het 'n glorieryke wese gewoon wat hoogmoedig geword het oor sy wysheid en skoonheid. Die skepper het hom daarom van die heilige berg afgegooi na die aarde toe (vgl. Von Rad, 1972:98).

Weens die sterk ooreenkomste met Oosterse skeppingsmites meen sommige teoloë dat Genesis 1-3 bestaande mites oorneem en daarom as mitologiese stof geïnterpreteer moet word. Bekende verteenwoordigers van die mitologiese verstaan is Hermann Gunkel en Claus Westermann.

Tydens die Verligting is mites verstaan as stories oor gode wat onhistories, vals en fiktief van aard is. Hierdie negatiewe siening van mites is deur Rudolf Bultmann na die teologie oorgedra in sy poging om die Skrif te ontmitologiseer (vgl. Westermann, 1974:12-13). Gunkel $(1984: 33,44)$ het die skeppingsverhale op 'n Bultmaniaanse 
wyse beskryf as etiologiese mites - 'n soort sprokie, wat ewige geestelike waarhede in 'n storievorm oordra.

In die twintigste eeu het belangrike ontwikkelings egter binne die teologie plaasgevind ten opsigte van die verstaan van die literêre aard en inhoudelike kenmerke van mites. Volgens Westermann (1974:12-13) het 'n besef ontstaan dat mites nie noodwendig as die teenpool van geskiedenis gesien moet word nie. Die antieke skeppingsmites het oorspronklik binne die konteks van oorlewing en die gevoel van bedreiging ontstaan. Hulle funksie was om sekuriteit te bied deur die bestaande realiteit in die lig van die oorsprong van die skepping te verklaar. 'n Verstaan van die begin van alle dinge lei tot 'n verstaan van die struktuur van die teenswoordige realiteit en dit skep 'n betekenisvolle kontinuïteit. Volgens Westermann (1974:13) moet die Bybelse skeppingsverhale in hierdie lig verstaan word. Daar kan alleen oor die oorsprong van die skepping nagedink en besin word deur "stories" daaroor te vertel. Die prehistoriese geskiedenis val immers buite die sfeer van menslike ervaring. Slegs deur die oorsprong van alle dinge voortdurend in herinnering te roep, kan die menslike geskiedenis as 'n betekenisvolle en kontinue gebeurtenis ervaar word.

Hoewel die skeppingsverhale mitologiese beelde gebruik wat in die Antieke Ooste in omloop was, is die skeppingsverhale duidelik nie mites nie. Die unieke kenmerk van mites is dat dit dramatiese en liriese taal gebruik om die verhouding tussen die natuurlike en geestelike realiteite in storievorm te beskryf as gebeure wat altyd en deurentyd waar is (vgl. Barth, 1958:84-85; Brueggemann, 1982:16; Paas, 2003:99). Die skeppingsverhale het daarteenoor 'n spesifieke fokus en gerigtheid. Dit bevat geen teogonieë wat die ontstaan van die skepping toeskryf aan 'n stryd tussen goddelike magte nie, en dit skryf ook geen ritueel voor wat mense in staat stel om die mitologiese drama te herhaal en daarmee beheer oor die strydende magte te behou nie. Tweedens is mites nie teosentries van aard nie, hoewel gode gewoonlik figure in mites is (vgl. Paas, 2003:98). Dit poog nie om die mens in 'n verhouding tot God te bring nie, maar wel om die struktuur van die realiteit en die enigma waarin die realiteit ditself bevind, te verklaar. Die skeppingsverhale is hierteenoor nie kosmologiese stof nie, maar uitsluitlik teosentriese stof wat oor kennis van God handel. Die nie-mitologiese aard van die skeppingsgegewens in die Bybel word waarskynlik die duidelikste geïllustreer in die feit dat dit demitologiserend en suiwerend met Antieke Oosterse skeppingsmites omgaan. Antieke sienings van die skepping word gedemitologiseer en in ' $n$ teologiese verhouding gebring met 
Jahweh se historiese verlossingsdade. Die Chaoskampf-beelde word byvoorbeeld in Genesis 1 en in poëtiese gedeeltes gebruik, maar geen religieuse betekenis word aan hierdie magte geheg nie. Die Chaoskampf is 'n gemaklike verwysingsbron vir Bybelskrywers om God se mag en soewereiniteit oor die bose uit te druk (vgl. Paas, 2003:79). Dit word weerspieël deur die nie-konstante en dikwels teenstrydige wyses waarop hierdie beelde gebruik word (vgl. McCarthy, 1984:84-85).

Die sterk ooreenkomste tussen Genesis 1-3 en die Babiloniese skeppingsverhale moet verklaar word in die lig daarvan dat Genesis 1-3 krities-polemiese stof is wat 'n korreksie bied op die Babiloniese skeppingsverhale (vgl. 4.4). Die Bybelskrywers maak gebruik van motiewe wat in die Babiloniese omgewing in omloop was, maar lewer as gevolg van die besondere openbaring 'n skeppingsleer, wat ten spyte van vele ooreenkomste totaal verskillend is (vgl. Du Toit, 1964:66). Mitologiese beelde word dus gebruik, maar die mitologiese inhoud word nie aanvaar nie.

Hoewel dele van Genesis 1-3 besonder beeldryk is en daarom sekerlik figuurlik verklaar moet word, spesifiek Genesis 3, het die verhale ook 'n historiese dimensie. Barth (1958:78-79) noem die skeppingsverhale "nie-historiese" geskiedenis. 2 Nie-histories in die sin dat dit nie eksakte, konkrete, historiese gebeure weergee nie, maar tog ' $n$ vorm van geskiedenis is, aangesien die historiese realiteite van God en die verbond van genade die kerntemas in die verhale is. God het immers werklik die skepping geskape en Hy beskerm werklik die skepping teen bedreiging. Hy het werklik in 'n verbond met die mens getree, die Bose bestaan werklik en die sondeval is 'n historiese werklikheid (vgl. ook König, 1988:41). Hierdie historiese werklikhede word in die skeppingsverhale in poëtiese, kunsprosaïese en paraboliese genres verpak.

2 Barth (1958:81) verwerp die beskrywing van die skeppingsverhale as mites, maar beskryf die skeppingsverhale as 'n degeneratiewe vorm van mite. Die skeppingsverhale is volgens Barth 'n sage wat deur middel van legendes en anekdotes 'n intuïtiewe en poëtiese weergawe gee van 'n pre-historiese realiteit binne die grense van tyd en ruimte. 


\section{Die skeppingsverhale as teologiese stof met 'n profetiese en polemiese gerigtheid}

\subsection{Skeppingsverhale as teologiese stof}

Volgens Berkhof (1986:162) was Calvyn en Luther die eerste teoloë wat in reaksie teen die Rooms Katolisisme benadruk het dat die skeppingsverhale as teologiese stof gelees moet word, en nie as stof wat kosmologiese kennis gee nie. Calvyn (1984, Inst. i:xiv:20) wys byvoorbeeld daarop dat die skeppingsverhale oor kennis van God handel en nie oor die struktuur van die wêreld nie.

Du Toit (1964:21) wys tereg daarop dat die gereformeerde belydenisskrifte slegs op die teologiese beginsels wat in die skeppingsverhale voorkom, fokus en dat dit die Bybelse woorde self gebruik. Dit probeer nie om die skeppingsverhale in sy kleinere besonderhede te verklaar nie (vgl. NGB, art. 8, 9, 12, 14 en die geloofsbelydenis van Nicea). Nêrens in die belydenisskrifte word 'n streng letterlike benadering as deel van ons belydenis oor die skeppingsverhale voorgehou nie. Inteendeel, NGB artikel 2 verklaar nadruklik dat die Skrif ons leer dit wat ons vir ons saligheid benodig.

Gereformeerde teoloë ná Calvyn is dit eens dat die Bybel nie as 'n wetenskaplike handboek gelees moet word nie, maar dat dit 'n religieuse bestemming het, en daarom as teologiese stof gelees moet word (vgl. Bavinck, 1928a:1:415; Berkhof, 1986:162; Vriezen, 1977: 361). Selfs die historiese stof in die Bybel het 'n teologiese en profetiese inhoud en gee nie eksakte, kontroleerbare, wetenskaplike feite nie (Bavinck, 1928a:361, 362). Die skeppingsverhale moet daarom ook as profetiese materiaal gelees word, maar dan nie as materiaal wat vooruitkyk nie, maar terugkyk (Du Toit, 1964:55). Die kenmerk van profetiese stof is dat dit nie kronologies is nie, maar momenteel gebeurtenisse weergee wat saaklik, maar nie histories nie, saamval. Konkreet-historiese en eskatologiese momente word dikwels nie van mekaar onderskei nie. Die dag van die Here (yom Yahweh) word byvoorbeeld as onmiddellik-komende voorgestel. Die profetiese aard van die skeppingsverhale bestaan daarin dat die stof die verlede en die hede aan mekaar verbind; die oorspronklike en die aktuele. Die geloof in die skepping is van fundamentele betekenis vir alle mense en niemand kan homself distansieer van die feit dat God alles geskape het nie (vgl. Paas, 2003:426). 


\subsection{Teologie in 'n natuurwetenskaplike omhulsel}

Ons vind in Genesis 1, soos op ander plekke in die Skrif, teologie in die natuurwetenskaplike omhulsel van 'n antieke tyd. Die Bybelse siening van die skepping moet egter nie verkeerd verstaan word as 'n primitiewe poging tot wetenskap nie. Die Bybel handel nie oor spekulatiewe vrae oor die oorsprong van die skepping nie, maar gebruik bloot die antieke wêreldbeeld van die tyd om hulle geloof in Jahweh te bely. Anderson (1994:4) haal in hierdie verband Ludwig Köhler aan:

The Old Testament story of creation does not answer the question: 'How did the world come into being?' with the answer: 'God created it,' but answers the question 'From where does the history of God's people derive its meaning?' with the answer: 'God has given the history of His people its meaning through creation.'

Die geosentriese wêreldbeeld in die Skrif sal probleme skep indien die Bybel, soos deur die meganiese inspirasieteorie, as 'n goddelike diktaat gehanteer word wat a-histories verklaar moet word. God dikteer egter nie op 'n meganiese wyse deur die Gees aan die Bybelskrywers nie. Ons kan die skrywers daarom nie uit hulle tyd lig nie. Die skrywers is mense wat in die Nabye Ooste gewoon het - 'n wêreld met sy eie kultuur, eie uitdrukkings en beperkte woordeskat. Hulle het hulle eie gawes en talente gehad, die letterkundige soorte van die tyd gebruik en gebruik gemaak van die natuurwetenskaplike opvattings van die tyd (vgl. Du Toit, 1964:26). Die wonder van die Godsopenbaring is egter dat God in en deur die taal van die tyd vir ons sy Woord bring. God gebruik ook die natuurwetenskaplike opvattings van die tyd om teologiese idees oor te dra. Indien die skeppingsverhale gehanteer word as teologiese stof met ' $n$ profetiese en polemiese gerigtheid, skep die geosentriese lewensbeeld geen probleme nie. Die uitweg uit die probleem van die geosentriese wêreldbeeld lê nie in die ontmitologisering van die Bybel soos Bultmann voorstel nie, maar in die verstaan van die Skrif binne sy eiesoortige konteks. Die wêreldbeeld op sigself is nie normatief nie, maar wel die goddelik-geïnspireerde teologie wat daarin vervat is (vgl. Du Toit, 1964:60). Hierdie perspektief bied ook lig op die verhouding tussen die teologie en die moderne natuurwetenskap. Die wetenskap versus geloof-debat oor die oorprong van die mens het tot 'n groot mate sy kontroversie verloor, aangesien albei kante besef dat die teologie en die natuurwetenskap op verskillende terreine beweeg en dat die debat eintlik 'n valse debat is (vgl. Westermann, 1974:47-48; Anderson, 1984:18). Die natuurwetenskap 
fokus nie op betekenis nie, maar op eksakte beskrywing en kontrole, terwyl die teologie op die uiteindelike sin en betekenis fokus. Binne die teologie is besef dat die skeppingsverhale nie vaste natuurwetenskaplike aannames maak nie, maar 'n verskeidenheid beskrywings van die skepping gee met komplementerende teologiese perspektiewe wat naas mekaar bestaan. Terselftertyd erken die natuurwetenskap die feit dat dit nie die bestaan van God kan bewys of ontken nie.

\subsection{Openbarings-historiese stof}

Die skeppingsverhale is teologiese stof wat 'n verduideliking gee van God se doel met die skepping en die relasie van God tot die mens. Genesis 1-3 bied nie wetenskaplike analises of gevolgtrekkings nie, maar beskryf die verhouding tussen God en die wêreld in die vorm van metafore, beelde en simbole wat in die antieke wêreld bekend was en wat waarhede uitdruk wat te kompleks is om op ander maniere uit te druk.

Dit skeppingsverhale behoort daarom teologies en profeties geïnterpreteer te word, en nie soos moderne geskiedskrywing in terme van oorsaak en gevolg nie. Die skeppingsverhale leer ons dat God alle dinge geskape het, nie hoe Hy alle dinge geskape het nie. Dit gee nie vir ons 'n eksakte, wetenskaplike en chronologiese beskrywing van skeppingsgebeure nie, maar lig eerder die groot momente uit. In kort: die Ou Testament bied nie 'n sistematiese teorie oor die oorsprong van die wêreld nie, maar vra geloof in God se skeppingsmag (Vischer, 2004:14).

In albei die Genesis-skeppingsverhale word die skepping ten nouste verbind aan die verlossingsgeskiedenis wat volg (vgl. Von Rad, 1984:60; Eichrodt, 1984:71). Genesis 1:1-2:4 is 'n mengsel van poësie en prosa wat ouer skeppingsverhale en kosmologieë gebruik en aanpas om Israel se verbondsverhouding met God te beskryf. Die teks het waarskynlik sy finale beslag gekry in die sesde eeu v.C. en dien as 'n korrektief op Babiloniese teologiese aansprake (vgl. Brueggemann, 1982:24-25; Eichrodt, 1967:67; Westermann, 1984: 90). Genesis 2:4b-3:24 word oor die algemeen toegeskryf aan 'n vroeëre Israelitiese tradisie wat klem geplaas het op Israel se godgegewe roeping in die wêreld. Israel se geskiedenis word beskryf as 'n geskiedenis wat betekenis gee aan die geskiedenis van alle nasies en die hele skepping. 'n Lyn word getrek tussen Israel se geskiedenis en die oorspronklike begin van die mensdom (vgl. Brueggemann, 1982:40). 
Die skeppingsleer funksioneer dus nie in die Bybel onafhanklik van die verlossingsgekiedenis nie, maar bied 'n inleiding tot die verbondsgeskiedenis wat volg vanaf Genesis 12 . Dit word onder meer weerspieël in die feit dat die Jahwistiese- en priesterlike skeppingsverhale heelwat jonger is as die Bybelse materiaal wat oor die uittog uit Egipte handel en van God se magtige verlossingdade vertel. Dit is opvallend dat die uittogverhale geensins na die skepping verwys nie. Anderson (1994:34) stel tereg dat die skeppingsleer in die Skrif 'n eskatologiese element bevat in die sin dat dit fokus op 'n toekomstige horison. God se skeppingsdade (bara) word byvoorbeeld in die profetiese literatuur as verlossingsdade beskryf (vgl. Eseg. 37; Jes. 43:14-19). Dit is in ooreenstemming met die Nuwe Testament se verstaan van die skepping as die selfopenbaring van God in die lewe, sterwe en opstanding van Christus (vgl. Joh. 1:1; 1 Kor. 15:28).

\section{4 'n Polemiese gerigtheid}

Soos reeds gemeld, het die skeppingsverhale 'n duidelike polemiese gerigtheid. Dit bied 'n korrektief op die skeppingsverhale van omringende volkere en stel die probleme wat uit hierdie verhale voortspruit in 'n nuwe lig (Vriezen, 1977:439). Ondanks die feit dat die verhale se beelde en uitdrukkingsvorms grootliks aan die oud-Oosterse skeppingsmites ontleen is, bied die inhoud 'n eiesoortige Israelitiese wêreldbeskouing wat profeties van aard is (Vriezen, 1977: 439). Enkele voorbeelde dien ter illustrasie:

- God word in Genesis 1 geopenbaar as die Skepper van hemel en aarde. Daarmee word gestel dat, behalwe dat God nie vergelykbaar is met die gode van die omringende volkere nie, Hy ook die enigste God is. Geen ander skepper van hemel en aarde kan tegelyk saam met God bestaan nie (vgl. Tsumura, 2005: 140).

- Genesis 1 beklemtoon dat God alleen goddelik is en dat niks in die skepping goddelik is nie. In die astrale kultusse van omringende volkere is die son en maan spesifiek as gode vereer (vgl. 2 Kon. 23:11 e.v.; Deut. 4:19). Dit is opmerklik dat Genesis 1 meld dat die son en maan eers op die derde dag geskape word, terwyl die lig al van die eerste dag af skyn. Daar word ook op 'n verkleinerende wyse na die son en maan as "ligte" verwys en sodoende word hulle beperkte funksie binne die skema van die skepping beklemtoon. 
- Die verhale verwerp die siening van skepping deur geboorte en afstamming heen. Hierdie siening het veral onder die politeïstiese skeppingsmites voorgekom wat 'n verskeidenheid gode veronderstel het. Volgens hierdie mites is die mens uit die gode gebore en stam dus ook van die gode af. Hierteenoor beklemtoon die Bybelse skeppingsverhale die transendente andersheid van God. Die mens is nie ' $n$ wese wat van God afstam nie, maar is 'n skepsel deur God geskape.

- In die Oosterse skeppingsmites kom gode, mens, dier, plant, sterre en materie voort uit 'n ongedifferensieërde chaotiese massa van 'n stoflike-geestelike aard. Albei die skeppingsverhale in Genesis beklemtoon egter dat die mens 'n unieke en eieoortige wese is wat op 'n besonderse wyse deur God geskape is (vgl. Vriezen, 1977:438).

- In verskeie Babiloniese en Sumeriese skeppingsmites word die mens se bestemming beskryf as diens aan die gode. Die taak van die mens is om die gode se werkslas te dra, sodat die gode kan rus. In die Bybelse skeppingsverhale is die mens se bestemming nie om die gode se werk te verrig nie, maar om kultuurvormend en beskawend met die aarde om te gaan.

- In die omringende volkere van Israel is die krag van vrugbaarheid vergoddelik. Die kultus van Baäl het hieruit voortgevloei. In die skeppingsverhale word egter beklemtoon dat God alleen goddelik is en dat voortplanting en vrugbaarheid die gevolg is van God se seënwoord (Gen. 1:26-28).

- Die Antieke Oosterse skeppingsmites beklemtoon dat die natuur deur bedreigende magte beheer word, terwyl die skeppingsverhale beklemtoon dat die natuur die skepping van God is en daarom goed is (vgl. Eichrodt, 1961:31).

- Teenoor die neiging in Babilonië om beelde van gode te maak en dinge in die skepping as afbeelding van die gode te sien, beklemtoon die priesterlike skeppingsverhaal dat die mens die beeld van God is. Die mens is die enigste deel van die realiteit wat iets van God kan reflekteer (vgl. Brueggemann, 1982:31-32).

- In teenstelling met die gode van Babilonië wat angstig oor hulle skepping waak, rus God volgens die priesterlike verhaal op die sewende dag. Hy skep nie, soos die gode van Babilonië, in stryd en onder dwang nie, maar ervaar vrede en rus ná sy skeppingswerk. 


\section{Implikasies vir die gereformeerde leer oor die erfsonde}

Die begrip erfsonde is nie 'n uitdrukking wat in die Skrif voorkom nie, maar is 'n term wat die kerkvader Augustinus ontwikkel het om die radikale verdorwenheid van die menslike geslag aan te dui. Hy het die begrip peccatum originale gebruik om aan te toon dat die menslike geslag inbegrepe is in die oorspronklike sonde van Adam en daarom in 'n staat van skuld voor God staan.

Dit is belangrik om daarop te let dat die kerk nie 'n geloof aan die erfsonde bely nie, maar aan die totale verdorwenheid van die mens. Erfsonde is bloot ' $n$ menslike term wat binne die teologie gebruik word om die totale verdorwenheid van die mens uit te druk. Die leer oor die erfsonde is een van die mees kontroversiële dogmas in die gereformeerde teologie. Die groot kritiekpunt teen die leer van die erfsonde gaan oor die persoonlike verantwoordbaarheid van die mens. Dit word dikwels beskryf as 'n fatalistiese dogma wat menslike skuld toeskryf aan die sonde van 'n ander persoon, sonder dat die mens werklik inherent self skuldig is. Die kernvraag is: Is dit die bedoeling van hierdie dogma om 'n kousale verduideliking te gee vir die eksistensiële krisis van die mensdom deur die skuld daarvoor op iemand anders te plaas (vgl. Berkouwer, 1971:425)?

Hoewel die woord erfsonde nie in die Skrif voorkom nie, kom die saak van die totale verdorwenheid en die generiese aard van die sonde duidelik na vore. Die skeppingsverhale is geen uitsondering nie. Genesis 3 stel die algemeenheid van die sonde en lei dit af van die val van die eerste mens.

\subsection{Die totale verdorwenheid van die mens in die skeppingsverhale}

Dit word soms verkeerdelik veronderstel dat die skepping in volmaakte harmonie geleef het tot en met die sondeval. Die stelling in Genesis 1 dat die skepping goed geskape is, word verkeerd verstaan as dat dit op volmaaktheid en perfeksie dui. In die konteks van Genesis 1 gaan dit egter daaroor dat elke ding gepas vir sy doel geskep is (vgl. Berkhof, 1986:176; Westermann, 1974:46; Anderson, 1984:13). Die begrip tob word in Genesis 1 in 'n estetiese sin gebruik, nie in 'n etiese sin nie (Anderson, 1984:15). In die Ou Testament verteenwoordig die duisternis, die waters bo, en die see bedreigende elemente wat 'n blywende bedreiging en gevaar vir die skepping inhou (vgl. Von Rad, 1972:54; König, 1988:17-18). Genesis 1 lê klem op die feit dat God die chaosmagte op 'n soewereine 
wyse onderwerp. Die begrippe woes en leeg (tōhǔ wa bōhǔ) dui op die chaosmagte wat die skepping bedreig. Duisternis (hōsek) en water (mayîm) verteenwoordig die twee hoofdimensies van chaos. God oorwin egter die chaosmagte deur telkens die gevaarlike elemente van die mensvriendelike elemente te skei. Lig en duisternis word byvoorbeeld van mekaar geskei, maar God noem net die skepping van lig goed. Die duisternis wat aan die begin bestaan het, word nie goed genoem nie. Die droë land word geskei van die see wat 'n bedreiging vir die skepping is (vgl. Ps. 104). Die tema van God wat seemonsters, soos die Rahab en Leviathan, met die skepping oorwin, word ook eksplisiet in ander dele van die Ou Testament gevind (vgl. Jes. 51:9-11; 27:1; Job 26:12; 40:25-41:26; Ps. 89:9-12; 74:12-14). In Genesis 1:6 word die firmament (uitspansel) geskape om die waters bo, van die waters onder te skei, sodat die aarde nie terugkeer na waterchaos nie.

Hoewel geen religieuse dimensie aan die chaosmagte toegeskryf word nie, verteenwoordig die chaosmagte dít wat God se skepping bedreig. Chaos het egter geen mag van sy eie nie en staan onder die heerskappy van God en die mag van God se skeppingswil (vgl. Von Rad, 1972:65). Tog is die gevaar van 'n terugval in chaos nie uitgesluit nie (vgl. Mathys, 2004:39). Hierdie realiteit word weerspieël wanneer die waters bo, met die sondvloed op die aarde neergelaat word. Ook in die Nuwe Testament is Christus se stryd met die bedreigende magte 'n belangrike tema (vgl. 1 Kor. 15:24-28; Mark. 1:21-28).

Die skeppingsverhale bied geen verklaring vir die voorkoms van die bose nie. Dit bly 'n onbeantwoorde raaisel. Die Jahwistiese skeppingsverhaal beklemtoon die misterie en paradoksale aard van boosheid. Die slang verteenwoordig boosheid wat, te midde van die goeie skepping, skielik te voorskyn kom. Die vertellers wil duidelik sê dat dit nie moontlik is om jouself met die oorsprong van boosheid te versoen nie en dat geen etiologie bestaan vir die oorsprong van boosheid nie (vgl. Westermann, 1974:92; Von Rad, 1972:87).

Die Jahwistiese narratief stel verder dat die begin van die sonde nie in God se skepping lê nie, maar in die menslike wil. God skape die mens met 'n vrye wil sodat hy kan kies tussen reg en verkeerd. Om waarlik God se beeld te kan wees en in 'n verhouding met God te kan leef, moet die mens vry wees. As God die mens nie geskape het met die vryheid om besluite te kan neem nie, sou die mens nie mens gewees het nie, maar 'n dier wat bloot deur instinkte gedryf word. Die mens is geskape om te kan dink, in verhoudings te tree en morele besluite te neem. Hoewel God die mens nie defektief 
geskape het nie, skep die mens se vrye wil tog die moontlikheid vir sonde. Sonde is potensieël deel van die mens se skepselmatige struktuur. Juis daarom stel God van die begin af grense aan die mens. Die mens word gewaarsku om nie van die boom van kennis van goed en kwaad te eet nie. Geen rede word vir die bevel gegee nie. Die mens moet bloot luister en gehoorsaam. Binne die teologie is daar al baie gedebatteer oor die betekenis van die boom van kennis van goed en kwaad. Volgens Westermann (1974:72) is die betekenis redelik eenvoudig: dit gaan oor kennis van dit wat bruikbaar en skadelik is vir die mens. Die gevaar bestaan dat die mens in sy strewe na kennis sy grense as kreatuurlike wese kan oortree. Westermann (1974:91) wys daarop dat die gebod 'n positiewe betekenis het. Dit is 'n Goddelike daad van vertroue in die mens. God neem die mens ernstig op as 'n wese wat in vryheid kan besluit en lojaal kan wees aan God.

$\mathrm{Na}$ die sondeval word die mens se skepselmatige potensialiteit tot sonde, aktualiteit. Terwyl die priesterlike verhaal beklemtoon dat God orde geskep het deur die chaosmagte te skei, beklemtoon die Jahwistiese narratief hoe die skepping weer deur chaos binnegedring word as gevolg van die sonde van die mens. Met die sondvloed word die chaosmagte (waters van bo) as 't ware op die aarde neergelaat. As gevolg van die misbruik van sy vryheid word die mens ' $n$ gebonde wese en sy staat van onskuld verander in ' $n$ staat van skuld. Die verbreidende en intensiviserende aard van die sonde word treffend geïllustreer in die hoofstukke wat op Genesis 3 volg. Die mens se versteurde verhouding met God brei uit na die familie (Gen. 4), geslagte (Gen. 4:23-24) en uiteindelik die hele wêreld (Gen. 6:5).

Hoewel teoloë soos Brueggemann (1982:41) en Westermann (1974:108-110) meen dat die idee van 'n sondeval en erfsonde vreemd is aan die skeppingsverhale, blyk dit duidelik uit die Jahwistiese skeppingsverhaal dat God die mens nie defektief geskape het nie, maar dat die sonde 'n bewuste keuse van die mens was. Die voortsetting van die Jahwistiese skeppingsverhaal vanaf Genesis 4 laat dit verder duidelik blyk dat, nadat die mens homself van sy kindskapsverhouding met God onttrek het, die sonde 'n houvas op die mens gekry het, en dat die sonde 'n verbreidende en intensiviserende uitwerking op die menslike geslag het. Weliswaar vind ons nie in die skeppingsverhale 'n dogma van erfsonde in 'n Christelik-dogmatiese sin nie, maar wel die grondslae waarvolgens Paulus tot sy konklusie oor die generiese aard van die sonde kan kom. Die vraag is: Hoe brei die sonde uit na alle mense? 


\subsection{Die verbreiding van die sonde}

\subsubsection{Die geneties-biologiese verstaan}

Die Roomse Konsilie van Trente het erfsonde as 'n geneties-biologiese begrip verstaan. Volgens die Konsilie het Adam as gevolg van sy sonde nie alleen geregtigheid verloor nie, maar sy liggaam en siel het in essensie verander. Gevolglik het hy sy sonde voortgeplant op die res van die menslike geslag (vgl. Bavinck, 3, 1929:7). In sommige gereformeerde kringe word die erfsonde dikwels misverstaan as 'n genetiese in plaas van 'n etiese en sedelike begrip, wat biologies van geslag tot geslag oorgedra word. Sodanige verstaan word begrond deur 'n bepaalde interpretasie van die geslagsregisters wat in Genesis 4 en 5 voorkom, asook tekse soos Psalm 51:7 en Romeine 5:12, en NGB artikel 15.

Die geslagsregisters van Genesis 4 en 5 sou daarop dui dat alle mense geneties van Adam afstam, terwyl Romeine 5:12 sou stel dat alle mense uit die bloed van Adam ontstaan het en dat sonde biologies van hom na die ganse menslike geslag oorgedra word. Hierdie siening word na bewering bevestig in NGB artikel 15 wat na die sonde verwys as 'n oorgeërfde gebrek.

Ten opsigte van die geslagsregisters moet daarteen gewaak word om nie 'n Westerse begrip van geskiedenis op 'n Antieke Oosterse teks af te dwing nie. Die persone wat in die geslagsregisters genoem word, was sekerlik historiese persone met wie God in 'n verbondsrelasie getree het. Desnieteenstaande is die geslagsregisters nie suiwer historiese stof nie, maar wel teologiese stof. Die genealogieë dui die oorsprong van die mensheid vanuit 'n bepaalde hoek aan, om sodoende iets besonders oor die wese van die mens en oor God te sê. Genesis 4 dui aan hoe die mens onder die vloek van sonde en verwyder van God, tog kultureel ontwikkel en beskawings kan skep (vgl. Westermann, 1974:21). Genesis 5 dui aan dat die voortgang en voortbestaan van die mens volledig die gevolg is van die kragtige seënwoord van God by die skepping van die mens. Die bedoeling van die geslagsregisters is dus om die gemeenskaplikheid van die ganse mensdom aan te toon: in die skepping en in die opeenvolging van die geslagte. Die intensie van die Jahwis is bloot om die universele omvang van sonde in ruimte en tyd uit te druk, nie om te sê dat die mens belas is met 'n genetiese noodlot nie (vgl. Berkhof, 1986:209).

Psalm 51 bevat geen dogma oor die wyse waarop die sonde van geslag tot geslag verbrei nie. Dit beklemtoon egter die totale ver- 
dorwenheid van die mens. Volgens Calvyn (1846:291) handel die Psalm daaroor dat die mens in homself skuldig staan voor God, en dat hy nie iemand anders vir sy skuld kan verkwalik nie. Die mens se sonde is totaal en kleef aan elke aspek van sy menswees. Hoe sonde vanaf ouers na kinders oorgedra word, is volgens Calvyn nie van belang nie. Hy weier om homself in misterieuse diskussies (labyrinthos) te begewe.

In Romeine 5:12 word in 'n korporatiewe sin na Adam en Christus verwys as twee figure wat verskillende aeons verteenwoordig. Paulus beklemtoon in Romeine 5 dat die genade in Christus groter is as die mag van die sonde in Adam. Die gevolgtrekking dat Romeine 5 'n histories-letterlike verklaring van Genesis 1 en 2 en 'n biologies-genetiese verstaan van die oordrag van sonde ondersteun, omdat dit bewys dat alle mense uit een bloed is, kom neer op 'n oorvraging van die teks (vgl. Berkhof, 1986:209). Paulus se stelling kan nie van die konteks waarbinne dit voorkom, geïsoleer word en dan gesistematiseer word om 'n dogma oor die verbreidende aard van sonde te skep nie (Berkhof, 1986:209). Paulus praat nie hier van Adam in 'n individualistiese sin nie, maar as prototipe van die ou mensheid. Net soos die sonde en die dood die gevolg is van ons verbondenheid met Adam, so is geregtigheid en die nuwe lewe 'n gevolg van ons verbondenheid met Jesus Christus. 'n Geneties-biologiese verklaring van Romeine 5:12 sal moet aanvaar dat gelowiges geneties van Christus afstam, aangesien Paulus betoog dat ons in Christus vernuwe word, soos ons in Adam verdorwe geraak het. 3 Dit is duidelik nie die bedoeling van Romeine 5 nie. Volgens Ridderbos (1966:60) gebruik Paulus in Romeine 5:12 korporatiewe en juridiese taal. Die gelowiges word in Christus forensies vry verklaar soos hulle in Adam skuldig verklaar is. Die mens se inbegrepenheid in Adam is soortgelyk aan die gelowige inbegrepenheid in Christus en dui daarom, soos in die geval van die inbegrepenheid in Christus, op 'n sedelike eenheid.

Arikel 15 van die NGB stel, soos Psalm 51, die feit dat die mens van geboorte af sedelik verdorwe is. Die mens word in 'n toestand van sonde gebore en ontvang. Polman (s.a., 1:271) en Berkouwer (1971:467) is dit egter eens dat Artikel 15, soos die Heidelbergse

3 Die begrippe eph' hoi pantes hemarton is in die Vulgaat vertaal as in Adam. Sedert die sestiende eeu is egter besef dat die vertaling verkeerd is en vertaal moet word as op grond van of as gevolg van Adam. Laasgenoemde vertaling maak 'n geneties-biologiese verstaan van sonde op grond van Romeine 5:12 onmoontlik. 
Kategismus, dit self nie uitlaat oor die verbreiding van die sonde nie. Volgens Polman (s.a., 1:270) beklemtoon Artikel 15 twee aspekte: die radikaliteit van die oorspronklike sonde en die deelname van die ganse menslike geslag aan die sonde. Die bedoeling van Artikel 15 is nie om die probleem van die oorerwing van sonde te hanteer nie, maar wel die totale verdorwenheid van die mens (Polman, 1940: 155).

Die siening van erfsonde as 'n geneties-biologiese begrip is nie slegs eksegeties onverantwoord nie, maar dogmaties gesproke ook problematies, want dit verontskuldig die mens as 'n blote slagoffer van Adam se daad. Volgens Berkouwer (1971:16) kan kousale denke alleen tot selfverontskuldiging lei. Hierdie benadering ontologiseer sonde en die etiese aspek van sonde en die gepaardgaande persoonlike verantwoordbaarheid van elke individu word daardeur verwaarloos (vgl. Heyns, 1978:192).

Volgens Bavinck $(1929: 78,80)$ dui die erfsonde daarop dat Adam se sonde ' $n$ invloed op die res van die menslike geslag het, maar dan as verteenwoordiger van die mensheid en nie in 'n fisiek-oordraagbare sin nie. Onder erfsonde behoort alleen verstaan te word dat die mens sedert sy geboorte sedelik verdorwe is; nie dat sonde geneties-biologies oorgeërf word nie. Die erfsonde is volgens Bavinck (1929:97) nie 'n fisiese begrip nie, maar 'n sedelike begrip:

De erfsonde is toch geene substantie, die zetelt in het liggaam en door generatie kan worden overgeplant; zij is een zedelijke qualiteit van den mensch, die de gemeenskap met God mist, welke hij naar zijne oorspronkelijke natuur bezitten moest en bezeten heft.

\subsection{Die realisme en foederalisme}

Binne die gereformeerde tradisie word hoofsaaklik twee verklarings gevind vir die verbreiding en uitwerking van die sonde, naamlik die realistiese en foederalistiese benadering. Die realistiese benadering, waarvan Shedd, Greijdanus en Schilder die vernaamste eksponente is, beklemtoon dat die mens self in en saam met Adam gesondig het (vgl. Bavinck, 1929:80). Die mensheid is sodanig in Adam begrepe dat die mensheid medesondaar saam met hom was. Adam verteenwoordig nie die mensheid nie - die mensheid is in hom teenwoordig. Hiersonder sou dit onregverdig van God wees om die mens vir die sonde van Adam verantwoordbaar te hou. Hoe die mens saam met Adam gesondig het, is volgens die meeste realiste nie van belang nie. Volgens Berkouwer (1971:440) kan die realisme hierdie vraag 
egter nie vermy nie. Hy vra tereg die vraag of die realistiese siening sou beteken dat die mens pre-eksistent in Adam gesondig het. Die realistiese benadering sal noodwendig moet veronderstel dat die mens 'n pre-eksisente bestaan voer. Hoe anders kan die samewerking met Adam voorgestel word (vgl. Heyns, 1978:192)? Bavinck (1929:81) stel dat die realistiese benadering noodwendig tot 'n algemene versoeningsleer moet lei. As alle mense daadwerklik in Adam meesondig omdat hulle in 'n realistiese en fisieke eenheid met hom staan, sou alle mense op 'n soortgelyke wyse in Christus verlos moet word, omdat Christus die menslike natuur aanneem.

Teenoor die realisme stel die foederalistiese benadering dat sonde in wese 'n verbondsbreuk met God is. God het met die eerste mens 'n verbond gesluit wat die eerste mens verbreek het. Die mens word veroordeel, nie op grond van 'n daadwerklike meesondig met Adam nie, maar staan in 'n forensiese staat van skuld vanweë sy relasie met Adam - die hoof van die verbond. Die probleem met hierdie siening is egter dat dit die verband tussen straf en skuld onderbeklemtoon. Straf op grond van 'n toegerekende skuld is onversoenbaar met God se regverdige oordeel. Dit is strydig met die wese van geregtigheid, naamlik om 'n skuld aan die mens toe te skryf op grond van die skuld van iemand anders (vgl. Berkouwer, 1971:426). Die Skrif stel duidelik dat die mens se skuld sy eie persoonlike skuld is en dat die mens daarom geen verskoning vir sy skuld het nie (vgl. Eseg. 18:4; 18:20; Rom. 3:19).

Myns insiens moet daarteen gewaak word om nie te teoreties met die kwessie van die verbreiding van sonde om te gaan nie, aangesien die Skrif geen sistematies uitgewerkte leer oor hierdie saak bied nie. Die feit van die totale verdorwenheid, die algemeenheid van die sonde en die skuld van die mens word bloot gestel. Tog gee Genesis 1-3 belangrike leidrade vir dié vraagstuk. Dit leer dat die mens nie buite God kan bestaan nie, want buite God is chaos. Die mens se verbreking van die verbond lei tot 'n versteurde verhouding met God wat 'n toestand van sonde op aarde veroorsaak, waarin alles van nature sedelik verdorwe raak. Die mens se skuld is dus sowel 'n reële as 'n toegerekende skuld. Toegerekend in die sin dat die mensheid vanaf geboorte korporatief gesproke verantwoording voor God verskuldig is oor die verbreking van die verbond. Reëel in die sin dat die sonde na die verbreking van die verbond ' $n$ sedelike toestand geword het. Sodra die mens homself buite die gemeenskap van God bevind, tree die toestand van sonde en chaos in. Die sonde is daarom in elke persoon nie alleen potensieel aanwesig nie, maar ook aktueel, aangesien die mens sy bestaan 
binne 'n ou aeon voer wat gekenmerk word deur 'n versteurde verhouding met God. Die mens leer nie hierdie sonde mettertyd aan nie, maar hy is inherent van nature en van geboorte af sondig (vgl. Ps. 51:7; NGB art. 14). Hierdie natuurlike verdorwenheid van die mens is nie daaraan te wyte dat die sonde deel is van sy geskape substansie en wese nie, maar wel daaraan dat hy van die begin af buite die volle gemeenskap met God leef en daarom in 'n toestand van sonde verkeer (vgl. Bavinck, 1929:101). Die erfsonde moet in verbondsterme en in reële terme verstaan word.

Die presiese ontstaan, verbreiding en werking van die natuurlike verdorwenheid is egter 'n misterie en van geen belang vir die geloof nie. Enige poging om die ontstaan en verbreiding van sonde in alle opsigte te verklaar, kan alleen dien om die mens te verontskuldig. Sonde is in wese afwykend, sinloos en onverstaanbaar en kan daarom nie sinvol verklaar word nie.

\section{Slotopmerking}

Binne die Gereformeerde Kerke in Suid-Afrika (GKSA) word die skeppingsverhale dikwels nog op grondvlak, spesifiek in kategese, as histories-letterlike stof hanteer. Dit is grootliks daaraan te wyte dat die skeppingsverhale, strydig met die gereformeerde belydenis, in die organiese inspirasieteorie, a-histories geïnterpreteer word. Die skeppingsgeloof in die Skrif het egter nie binne 'n historiese vakuum ontstaan nie, maar het ontwikkel binne die denkwêreld van die Antieke Ooste. Israel kon sy geskiedenis en historiese ontmoetings met God alleen binne hierdie horison verstaan. Barth (1958:82) stel tereg dat die idee dat die Skrif alleen gesagvol kan wees indien dit histories-letterlik spreek, onhoudbaar is en deur die Christelike kerk laat vaar moet word. Dit is juis op grond van hierdie uitgangspunt dat die liberale teologie sekere dele van die Skrif wou ontmitologiseer. 'n Histories-letterlike verklaring van Genesis 1-3 het absurde implikasies, bring die gesag van die Skrif in gedrang en lei tot onhoudbare dogmatiese redenasies soos dat sonde biologies-geneties van geslag tot geslag oorgedra word. 'n Verstaan van Genesis 1-3 as teologiese stof met 'n polemiese gerigtheid, laat groter reg geskied aan die boodskap van Genesis 1-3.

\section{Geraadpleegde bronne}

ANDERSON, B.W. 1984. Mythopoeic and theological dimensions of Biblical creation faith. (In Anderson, B.W., ed. Creation in the Old Testament. Philadelphia: Fortress. p. 1-25.) 
ANDERSON, B.W. 1994. From creation to new creation: Old Testament perspectives. Minneapolis: Fortress.

BARTH, K. 1958. The doctrine of creation: church dogmatics 3:1. Edinburgh: Clark.

BAVINCK, H. 1928a. Gereformeerde dogmatiek. DI. 1. Kampen: Kok.

BAVINCK, H. 1928b. Gereformeerde dogmatiek. DI. 2. Kampen: Kok.

BAVINCK, H. 1929. Gereformeerde dogmatiek. DI. 3. Kampen: Kok.

BERKHOF, H. 1986. Christian faith. Grand Rapids: Eerdmans.

BERKHOF, L. 1958. Systematic theology. Grand Rapids: Banner of Truth Trust.

BERKOUWER, G.C. 1971. Sin. Transl. by P.C. Holtrop. Grand Rapids: Eerdmans.

BRUEGGEMANN, W. 1982. Genesis: a Bible commentary for teaching and preaching. Atlanta: John Knox.

CALVYN, J. 1846. Commentary on the book of Psalms. Transl. by J. Anderson. Edinburgh: Calvin Translation Society.

CALVYN, J. 1984. Institusie van die Christelike godsdiens. Vert. deur H.W. Simpson. Potchefstroom: Calvyn Jubileumboekefonds.

DU TOIT, S. 1964. Bybel, skepping en evolusie. Johannesburg: Voortrekkerpers.

EICHRODT, W. 1961. Man in the Old Testament. Transl. by K. \& R. Gregor Smith. London: SCM.

EICHRODT, W. 1967. Theology of the Old Testament. London: SCM.

EICHRODT, W. 1984. In the beginning: a contribution to the interpretation of the first word of the Bible. (In Anderson, B.W., ed. Creation in the Old Testament. Philadelphia: Fortress. p. 65-74.)

GUNKEL, H. 1984. The influence of Babylonian mythology upon the Biblical creation story. (In Anderson, B.W., ed. Creation in the Old Testament. Philadelphia: Fortress. p. 25-53.)

HEYNS, J.A. 1978. Dogmatiek. Pretoria: NG Kerkboekhandel.

KÖNIG, A. 1988. New and greater things: re-evaluating the Biblical message on creation. Pretoria: University of South Africa.

KUYPER. A. s.a. Locus de sacra scriptura, creatione, creaturis. Kampen: Kok.

MATHYS, H.P. 2004. Creation in the Old Testament: an overview. (In Vischer, L., ed. Listening to creation groaning. Geneva: Centré International Réformé. p. 35-61.)

McCARTHY, D.J. 1984. Creation motifs in ancient Hebrew poetry. (In Anderson, B.W., ed. Creation in the Old Testament. Philadelphia: Fortress. p. 74-90.)

NEDERLANDSE GELOOFSBELYDENIS. 1999. Die berymde Psalms. Potchefstroom: Administratiewe Buro.

NGB

kyk NEDERLANDSE GELOOFSBELYDENIS

PAAS, S. 2003. Creation and judgement: creation texts in some eight century prophets. Leiden: Brill.

POLMAN, A.D.R. S.a. Woord en belijdenis: eenvoudige verklaring van de Nederlandse Geloofsbelijdenis. DI. 1. Franeker: Wever.

POLMAN, A.D.R. 1940. Onze Nederlandse Geloofsbelijdenis: verklaard uit het verlede: gekonfronteerd met het heden. DI. 2. Franeker: Wever.

RIDDERBOS, H. 1966. Paulus: ontwerp van zijn theologie. Kampen: Kok. 
ROGERSON, J.W. 2001. Genesis 1-11. (In Rogerson, J.W., Moberly, R.W.L. \& Johnstone, W., eds. Genesis and Exodus. Sheffield: Sheffield Academic Press. p. 1-60.)

TSUMURA, D.T. 2005. Creation and destruction: a reappraisal of the Chaoskampf theory in the Old Testament. Indiana: Eisenbrauns.

TURNER, L.A. 2000. Genesis. Bath: Sheffield Academic Press.

VELEMA, W.H \& VAN GENDEREN, J. 1992. Beknopte gereformeerde dogmatiek. Kampen: Kok.

VISCHER, L. 2004. Listening to creation groaning. (In Vischer, L., ed. Listening to creation groaning. Geneva: Centré International Réformé. p. 11-35.)

VON RAD, G. 1972. Genesis. London: SCM.

VON RAD, G. 1984. The theological problem of the Old Testament doctrin of creation. (In Anderson, B.W., ed. Creation in the Old Testament. Philadelphia: Fortress. p. 53-65.)

VRIEZEN, T.H.C. 1977. Hoofdlijnen der theologie van het Oude Testament. Wageningen: Veenmanen.

WESTERMANN, C. 1974. Creation. Transl. by J.J Scullion. Philadelphia: Fortress.

WESTERMANN, C. 1984. Genesis 1-11: a commentary. Transl. by J.J. Scullion. Minneapolis: Augsburg.

WHITE, L. 1967. The historical roots of our ecological crisis. Science: 12031207, Mar.

Kernbegrippe:

erfsonde

foederalisme

polemies

realisme

skepping

Key concepts:

creation

foederalism

original

polemic

realism

$\sin$ 
